Article

\title{
Acceptance of New Land-Use Activities by Hmong and Khmu Ethnic Groups: A Case Study in Northern Lao People's Democratic Republic
}

\author{
Natsuko Kobayashi ${ }^{1}$, Chaloun Bounithiphonh ${ }^{2}$, Phonevilay Sichanthongthip ${ }^{2}$, Chanhsamone Phongoudome ${ }^{2}$ \\ and Motoshi Hiratsuka ${ }^{1, *(D)}$ \\ 1 Faculty of Human Sciences, Waseda University, Tokorozawa, Saitama 359-1192, Japan; \\ natsuko.bbhbfs@moegi.waseda.jp \\ 2 National Agriculture and Forestry Research Institute, Ministry of Agriculture and Forestry, \\ Vientiane P.O. Box 7170, Laos; chalounb@yahoo.com (C.B.); sphonevilay@yahoo.com (P.S.); \\ houaykhing@gmail.com (C.P.) \\ * Correspondence: hiratsuka@waseda.jp
}

check for updates

Citation: Kobayashi, N.; Bounithiphonh, C.; Sichanthongthip, P.; Phongoudome, C.; Hiratsuka, M. Acceptance of New Land-Use Activities by Hmong and Khmu Ethnic Groups: A Case Study in Northern Lao People's Democratic Republic. Forests 2022, 13, 8. https:// doi.org/10.3390/f13010008

Academic Editors: Rosa Gallardo-Cobos, Pedro

Sánchez-Zamora and

Pilar Fernandez-Rebollo

Received: 11 November 2021

Accepted: 16 December 2021

Published: 21 December 2021

Publisher's Note: MDPI stays neutral with regard to jurisdictional claims in published maps and institutional affiliations.

Copyright: (C) 2021 by the authors. Licensee MDPI, Basel, Switzerland. This article is an open access article distributed under the terms and conditions of the Creative Commons Attribution (CC BY) license (https:// creativecommons.org/licenses/by/ $4.0 /)$
Abstract: Reducing emissions from deforestation and forest degradation (REDD+) to address climate change has historically included little evaluation of how heterogeneous local communities respond to REDD+ interventions and new land-use activities. We assessed differences in the acceptance of new land-use activities as a function of livelihoods of the Hmong and Khmu ethnic groups in northern Lao People's Democratic Republic, where REDD+ was implemented between 2011 and 2018. Our socioeconomic data, collected by a questionnaire-based survey and focal group discussions, showed that the Hmong more effectively incorporated support from REDD+ than the Khmu because the Hmong owned grazing land. Our findings highlight the importance of understanding the capabilities and characteristics of each ethnic group when implementing new land-use activities (i.e., designing and implementing alternative livelihoods) within a target area to ensure distributional equity in heterogeneous communities. Such a consideration should be included in land-use policy and also be a part of the social safeguards in the land-use sector.

Keywords: ethnic groups; livestock raising; income gap; shifting cultivation; social equity; different capability; rural area; rural development; climate change; reducing emissions

\section{Introduction}

Globally, greenhouse gas (GHG) emissions from agriculture, forestry and other landuses account for approximately $23 \%$ of all GHG emissions, the greater part of which are from developing countries [1,2]. Analysis of the drivers of deforestation and forest degradation indicates that shifting cultivation aimed at food production is a preeminent driver in tropical regions [3]. Thus, reducing emissions from deforestation and forest degradation (REDD+) should consider a balance between addressing climate change and addressing social development [4]. The United Nations Framework Convention on Climate Change (UNFCCC) conference at Cancun aligned these considerations as social safeguards [5]. Adopting these measures provides social safeguards, especially in rural areas [6,7]. This is critically important where livelihoods are dependent on forest resources [8-11]. In addition, new land-uses, such as large-scale plantation development initiated externally (e.g., by other countries), are being introduced in developing countries. When such new land-use activities are adopted in the rural areas of developing countries, social safeguards are important to maintain the stability of livelihoods.

The interventions on local communities can have both positive and negative impacts [12]. On the positive side, for example, Atela et al. [13] reported that communal livelihood projects, as part of the REDD+ implementations, improved assets in lowwealth households. Moreover, improved governance was reported following a REDD+ 
intervention-specifically, the participation of indigenous women in decision making in Nepal [14]. However, several studies have revealed negative impacts, such as regulatory activities which prohibit access to forest resources, that have caused food insecurity $[15,16]$. Other studies have suggested that local people obtain unequal benefits from REDD+ interventions, depending on the type of social group they belong to $[17,18]$. Furthermore, Satyal et al. [19] reported that poorer people in villages who are more likely to depend on forest resources tend to receive less benefit from outside, because they cannot afford the time to participate in decision-making.

The present study was conducted in the northern Lao People's Democratic Republic (hereafter Lao PDR). Lao PDR had not established land-use policies that considered external collaboration and was also involved in a REDD+ readiness and demonstration project (i.e., introduction of new land-use activities) from 2011 to 2018, using a phased approach. Such an approach aims to ensure that developing countries can implement mitigation actions in accordance with their respective national capabilities and circumstances [5]. We chose this location for our case study because: (1) this region was suitable for assessing rural people's livelihoods and any regional transitions after the REDD+ project had been implemented for several years; (2) villagers living in the mountainous areas are heavily dependent on natural resources [20] and are analyzed as agents of deforestation and forest degradation [21,22]; and (3) the area is home to the Hmong and Khmu ethnic groups, both of whom are predominant in northern Lao PDR, although possessing different capabilities [23,24].

Our aims were to assess the variation in acceptance of land-use activities introduced by the REDD+ intervention as a function of the villagers' livelihoods. We identified differences in acceptance levels of land-use activities that introduced alternative livelihoods (e.g., livestock raising) instead of shifting cultivation within different ethnic groups.

\section{Study Site and REDD+ Project Description}

\subsection{Study Site Description}

The study was conducted in two villages, Houaykhing and Houayha, within the Houaykhing Village Cluster (HKVC) in Phonxay district, Luang Prabang Province (Figure 1). The HKVC is located in a northern mountainous area, with elevations ranging from 324 to $2106 \mathrm{~m}$ above sea level and an average altitude of $908 \mathrm{~m}$. It is $105 \mathrm{~km}$ north of the city of Luang Prabang, approximately three and half hours from the city by car during the dry season. During the rainy season, this area is difficult to access by road. More detailed environmental characteristics are reported elsewhere [21].

The main livelihood for the villagers in this region is shifting cultivation, with rice produced mostly for self-consumption. Although the villagers engage in other incomegenerating activities, such as raising livestock and collecting non-timber forest products (NTFPs), shifting cultivation remains a very important part of their livelihood [25]. Each type of livelihood has a different impact on the forests: shifting cultivation has a negative impact on forests, especially when the fallow period is shortened [26]; collection of NTFPs has a positive impact on forests if it is done sustainably [27]; and livestock raising has mixed impacts on forests because it enables villagers to reduce their dependency on shifting cultivation [25] but it enhances the conversion of fallow land to grazing land, which prevents fallow land from regenerating [23].

\subsection{Implementation of New Land-Use Activities}

From December 2011 to August 2014, these villages were targeted intensively by a REDD+ readiness project implemented as part of the Participatory Land and Forest Management Project for Reducing Deforestation in Lao PDR, supported by the Japan International Cooperation Agency [25]. A demonstration phase, from 2013 to 2018, as defined by UNFCCC [5], was also conducted under the Joint Crediting Mechanism, as agreed by the governments of Lao PDR and Japan. The detailed interventions of REDD+ in the HKVC were separated into two phases of readiness and demonstration. The former was as follows: (1) raising awareness of forest conservation; (2) understanding villagers' 
needs for alternative livelihoods; and (3) establishing village funds and organizing the land and forest management committees to manage forests. The latter consisted of several activities, such as agricultural training, the introduction of new agricultural activities, the enhancement of group activities and the introduction of alternative livelihoods, namely the enhancement of livestock raising with the provision of vaccinations. The enhancement of livestock raising was the central activity [23]. Thus, "new land-use activities" in this paper refers to support for raising livestock. While the readiness phase was focused on financial support for purchasing livestock for the new land-use activities, the demonstration phase focused on non-financial support, namely knowledge and technology transfer as well as training.

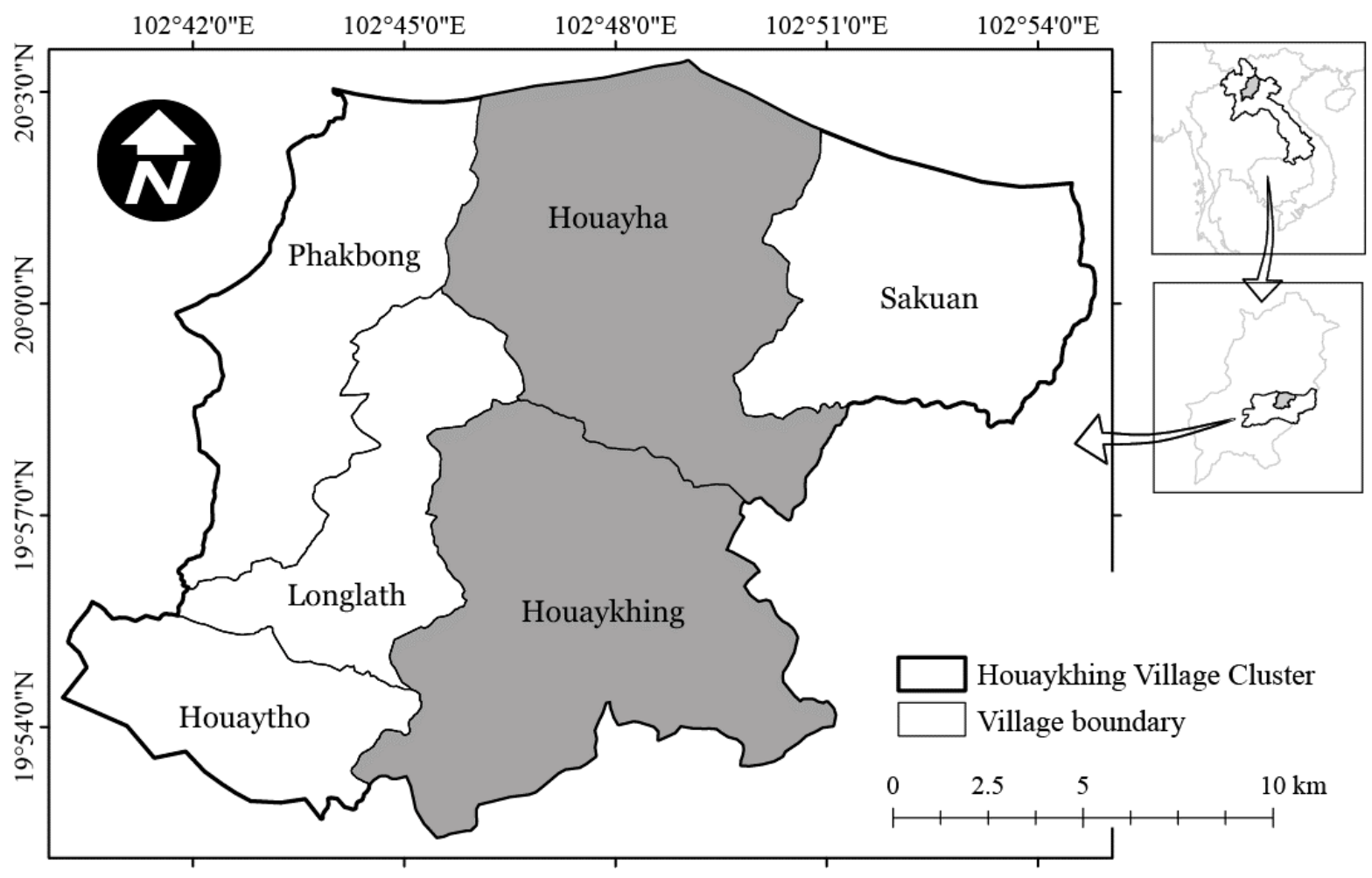

Figure 1. Location of the villages of Houaykhing and Houayha, within the Houaykhing Village Cluster in Phonxay district, Luang Prabang Province of Lao People's Democratic Republic.

Out of the six HKVC villages we chose Houaykhing and Houayha villages as study sites because they are in the geographical center of the cluster. Houaykhing is located $36 \mathrm{~km}$ from the district center and covers approximately 7971 ha. In 2019, there were 242 households in Houaykhing, with a total population of 1538. The village was home to two predominant ethnic groups, the Hmong and $\mathrm{Khmu}$, each representing approximately $50 \%$ of the population. The village was established in 2003 by merging three villages into one along the main road [25]. Houayha is located $38 \mathrm{~km}$ from the district center and covers approximately $8295 \mathrm{ha}$. It is $3 \mathrm{~km}$ from the main road and has no electricity (Table 1). In 2019, there were 61 households in Houayha, with a total population of 442. Most of the villagers were Hmong (53 households out of 61) (Table 1). The Hmong and Khmu differ in their historical and current agricultural production methods: the Hmong traditionally grew high-value opium and owned cattle as their primary livestock; thus, they had more assets and were often able to buy more agricultural land than the Khmu. The Khmu traditionally raised small livestock, such as pigs and poultry [28]. 
Table 1. General information about the villages of Houaykhing and Houayha in 2019.

\begin{tabular}{|c|c|c|c|c|c|}
\hline \multirow{2}{*}{ Village Name } & \multicolumn{3}{|c|}{$\begin{array}{l}\text { Number of Households and Population in } \\
\text { Each Ethnic Group }\end{array}$} & \multirow{2}{*}{ Characteristics of Social Infrastructure } & \multirow{2}{*}{$\begin{array}{l}\text { Other Facilities } \\
\text { and Characteristics }\end{array}$} \\
\hline & Ethnicity & Household & Population & & \\
\hline \multirow{4}{*}{ Houaykhing } & Hmong & 117 & 726 & \multirow{4}{*}{$\begin{array}{l}\text { Village has a primary school and the } \\
\text { junior high school for the village cluster; } \\
\text { running water; electricity; and fronts } \\
\text { onto the main road. }\end{array}$} & \multirow{4}{*}{$\begin{array}{l}\text { There is an agricultural training } \\
\text { center; clinic and an office for } \\
\text { the village cluster. }\end{array}$} \\
\hline & Khmu & 120 & 784 & & \\
\hline & Lao Loum & 5 & 28 & & \\
\hline & Total & 242 & 1538 & & \\
\hline \multirow{4}{*}{ Houayha } & Hmong & 53 & 392 & \multirow{4}{*}{$\begin{array}{l}\text { Village has a primary school; running } \\
\text { water; no electricity and is } 3 \mathrm{~km} \text { away } \\
\text { from the main road. }\end{array}$} & \multirow{4}{*}{$\begin{array}{l}\text { There are no specific facilities, } \\
\text { but it has the largest land area } \\
\text { (as a natural resource) within } \\
\text { the village cluster. }\end{array}$} \\
\hline & Khmu & 8 & 50 & & \\
\hline & Lao Loum & 0 & 0 & & \\
\hline & Total & 61 & 442 & & \\
\hline
\end{tabular}

From 2005 to 2010 (before the REDD+ project), the area of evergreen and deciduous mixed forest was decreasing at an annual rate of $3.0 \%$ within both Houaykhing and Houayha village environs. This rate of decrease was slowed by the REDD+ demonstration (to 1.6\% from 2015 to 2018). There was also an obvious increase in grassland and shrub (i.e., grazing land), at an annual rate of $14.1 \%$ (571 ha in 2005 and 1615 ha in 2018) (Figure 2), because of the conversion of fallow land into grazing land for raising livestock. On the basis of overall land and forest dynamics, which were mainly a function of the conservation of mixed forest and old fallow with high carbon density during REDD+ projects, the reduction of GHG emissions was evaluated as successful [23].

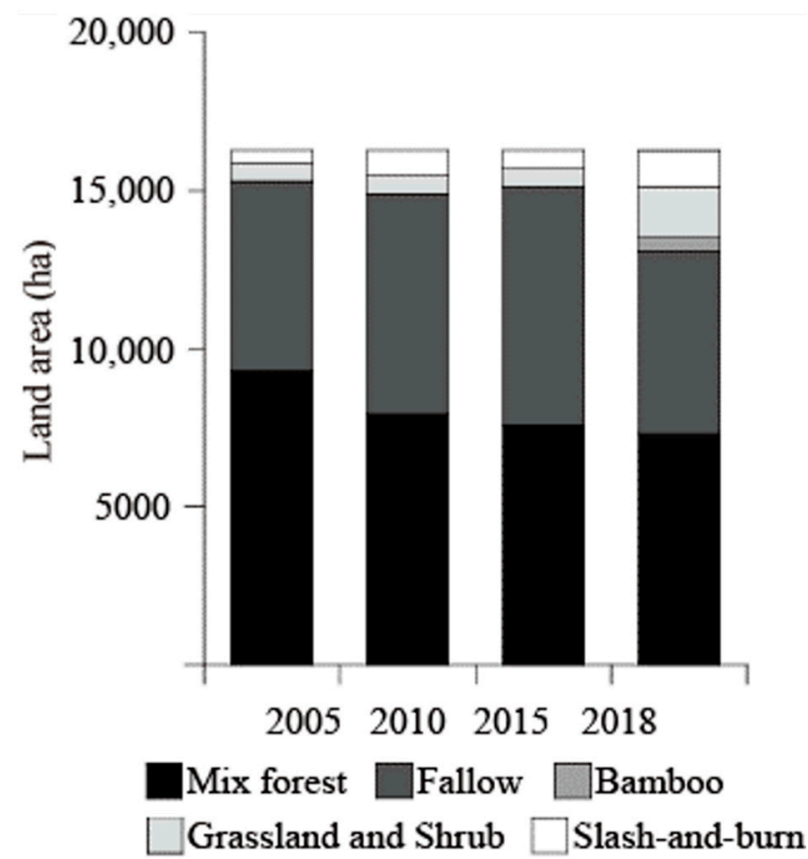

Figure 2. Land and forest cover dynamics in the villages of Houaykhing and Houayha, 2005-2018 (Data from Hiratsuka et al. [23]).

\section{Materials and Methods}

\subsection{Questionnaire-Based Socioeconomic Survey}

To identify the impact of variation in acceptance of the new land-use activities on livelihoods, we conducted a survey using semi-structured questionnaires and focus group discussions in June 2019. The interviews, targeting 60 households, were conducted face-toface, in the Lao language. The questionnaire covered five categories of information: (1) basic information (e.g., family size and ethnicity); (2) livestock and land assets; (3) income and expenditure; (4) status of working conditions (e.g., importance of group activities and knowledge-sharing); and (5) satisfaction with livelihood. Data for both 2013, which was 
just after the REDD+ project had started and 2019 were collected. Thirty households from each village (representing $12 \%$ of the total households in Houaykhing and $49 \%$ in Houayha) were selected for the interviews using a stratified sampling method, which captured both ethnicities and whether the households were supported by REDD+. In total, $23 \mathrm{Khmu}$ and 37 Hmong households were surveyed. In addition, we collected supplementary information on the land-use system in the villages from focal group discussions with village authorities, women and shifting cultivation farmers.

\subsection{Data Analysis}

All the data were compared using averages and standard deviations (SDs), to help determine the characteristics of the study populations. A $t$-test and Wilcoxon signed-rank test (each variable's normality was first tested using a Shapiro-Wilk test before conducting the $t$-test and the Wilcoxon signed-rank test), canonical discriminant analysis (CDA) and principal component analysis (PCA) were conducted using IBM SPSS Statistics Ver. 26 (SPSS Inc., Chicago, IL, USA). The following procedure was applied for the statistical analysis: (1) the characteristics of each ethnic group were confirmed by comparing assets (possession of livestock and land-use rights) and income sources; (2) a CDA was used to clarify the variables that separated each ethnic group; and (3) a PCA was used to capture the current status of the community, visualize the distribution of land-use rights and assess the value given to cooperation within the community. According to previous research [23,29], a CDA is useful for identifying the important factors that characterize multiple types of objects, such as ethnic groups, while a PCA can be used to visually understand the community's characteristics by reducing the number of socioeconomic factors [29,30]. For the CDA, we assumed multivariate normality and confirmed that our data were not highly correlated $(<0.7)$. The explanatory variables were chosen using a stepwise selection process. We did not apply the existing framework (i.e., [31]) during the analysis. This was because that targeted external interference (i.e., REDD+) was thought to be beyond the scope of the existing framework. We used the framework to discuss our results.

\section{Results}

\subsection{Acceptance of Livestock Raising and Related Land Assets}

A comparison of livestock and owned land-use rights between 2013 and 2019 revealed distinctive differences in the ethnic groups (Table 2). While the Hmong villagers significantly increased the number of their owned livestock, namely cows (approximately 1.9 times), buffalo (1.5 times) and goats (2.5 times) $(p<0.01, p<0.05, p<0.05$, respectively, according to the Wilcoxon signed-rank test), the Khmu villagers showed a slight decrease in all livestock, with a significant decrease in poultry $(p<0.05$, according to the Wilcoxon signed-rank test) because a lack of vaccinations led to more livestock disease.

Table 2. Comparisons of average livestock ownership and income generation with standard deviation (SD) for Hmong and Khmu ethnicities for 2013 and 2019.

\begin{tabular}{|c|c|c|c|c|c|c|c|c|c|c|c|c|c|}
\hline & & \multicolumn{5}{|c|}{ Hmong } & \multirow{3}{*}{ Significance } & \multicolumn{5}{|c|}{ Khmu } & \multirow{3}{*}{ Significance } \\
\hline & & \multirow{2}{*}{$\begin{array}{l}\text { Sample } \\
\text { Number }\end{array}$} & \multicolumn{2}{|c|}{2013} & \multicolumn{2}{|c|}{2019} & & \multirow{2}{*}{$\begin{array}{l}\text { Sample } \\
\text { Number }\end{array}$} & \multicolumn{2}{|c|}{2013} & \multicolumn{2}{|c|}{2019} & \\
\hline & & & Ave. & SD & Ave. & SD & & & Ave. & SD & Ave. & SD & \\
\hline \multirow{5}{*}{$\begin{array}{c}\text { Number of } \\
\text { owned livestock }\end{array}$} & Cows & 37 & 3.59 & 3.70 & 6.89 & 7.35 & $p<0.01$ & 23 & 2.96 & 6.72 & 1.30 & 2.64 & ns \\
\hline & Buffalo & 37 & 3.51 & 4.34 & 5.14 & 5.85 & $p<0.05$ & 23 & 2.13 & 3.06 & 1.74 & 2.65 & ns \\
\hline & Pigs & 37 & 5.89 & 4.34 & 7.59 & 7.34 & ns & 23 & 6.52 & 10.75 & 3.17 & 3.66 & ns \\
\hline & Goats & 37 & 1.89 & 3.19 & 4.68 & 7.41 & $p<0.05$ & 23 & 6.87 & 13.23 & 2.04 & 5.77 & ns \\
\hline & Poutry & 37 & 40.24 & 32.21 & 38.27 & 39.74 & ns & 23 & 39.43 & 49.41 & 19.65 & 24.18 & $p<0.05$ \\
\hline \multicolumn{2}{|c|}{$\begin{array}{l}\text { Livestock income } \\
\text { (thousand Kip) }\end{array}$} & 37 & 12,489 & 16,617 & 13,863 & 17,203 & ns & 23 & 11,753 & 14,688 & 10,443 & 13,059 & ns \\
\hline
\end{tabular}

Significance set according to a Wilcoxon signed-rank test; Wilcoxon signed-rank test was conducted after a Shapiro-Wilk test to test each variable's normality; ns stands for not significant. Kip, Laos's national currency: 1000 Kip is approximately 0.1 USD according to the rate in 2019. 
The owned land-use rights of both the Hmong and Khmu showed similar trends: the area of slash-and-burn less than one year after slash-and-burn cultivation significantly decreased while the area of grazing land increased. However, the Hmong villagers owned a significantly larger area of grazing land than the Khmu in 2019 (2.84 and 1.32 ha per household, respectively; $p<0.01$, according to the Wilcoxon signed-rank test). This tendency has also been reported elsewhere [23]. Such livelihood changes influenced the income generation per household in the REDD+ targeted villages. The Gini coefficient calculated from these values for both the Hmong and the Khmu showed a slight increase from $46.4 \%$ in 2013 to $48.7 \%$ in 2019. Thus, the new land-use activities, which focused on livestock raising, did not reduce income gap among households nor stabilize social conditions.

To elucidate whether the variables related to livestock raising activities were important when classifying ethnic groups, a CDA was conducted. To this end, the following explanatory variables were used: number of owned livestock, income from livestock raising (shown in Table 2) and owned grazing land area (shown in Table 3). The CDA clarified the differences between the ethnic groups regarding acceptance of livestock raising as supported by REDD+ (Table 4). Overall, $81.7 \%$ of the variables classified the ethnic group correctly in 2019, which meant that the variables related to livestock raising activities were appropriate to distinguish the differences between the Hmong and Khmu (Table 5).

Table 3. Average areas (ha) of land-use rights with standard deviation (SD) owned by the Hmong and Khmu ethnic groups.

\begin{tabular}{|c|c|c|c|c|c|c|c|c|c|c|c|c|}
\hline & \multicolumn{5}{|c|}{ Hmong } & \multirow{3}{*}{ Significance } & \multicolumn{5}{|c|}{ Khmu } & \multirow{3}{*}{ Significance } \\
\hline & \multirow{2}{*}{$\begin{array}{l}\text { Sample } \\
\text { Number }\end{array}$} & \multicolumn{2}{|c|}{2013} & \multicolumn{2}{|c|}{2019} & & \multirow{2}{*}{$\begin{array}{l}\text { Sample } \\
\text { Number }\end{array}$} & \multicolumn{2}{|c|}{2013} & \multicolumn{2}{|c|}{2019} & \\
\hline & & Ave. & SD & Ave. & SD & & & Ave. & SD & Ave. & SD & \\
\hline Area of slash-and-burn (ha) & 37 & 2.16 & 1.41 & 1.77 & 1.10 & $p<0.05$ & 23 & 2.77 & 2.89 & 2.01 & 1.05 & $p<0.05$ \\
\hline Area of fallow(ha) & 37 & 5.38 & 3.06 & 2.88 & 2.21 & $p<0.01$ & 23 & 5.07 & 3.91 & 4.11 & 3.54 & ns \\
\hline Area of grazing land (ha) & 37 & 0.26 & 0.71 & 2.84 & 1.72 & $p<0.01$ & 23 & 0.09 & 0.33 & 1.32 & 1.37 & $p<0.01$ \\
\hline Total area owned (ha) & 37 & 7.79 & 3.58 & 7.92 & 3.08 & ns & 23 & 7.93 & 5.23 & 7.66 & 4.59 & ns \\
\hline
\end{tabular}

Significance set according to a Wilcoxon signed-rank test and $t$-test according to each variable's normality; all variables except total area owned were tested by a Wilcoxon signed-rank test; ns stands for not significant.

Table 4. Livestock-related explanatory variables with standardized canonical discriminant function coefficients.

\begin{tabular}{cc}
\hline & $\begin{array}{c}\text { Standardized Canonical Discriminant } \\
\text { Explanatory Variables }\end{array}$ \\
\cline { 2 - 2 } & Function Coefficients \\
\hline Number of cows owned in 2019 1 \\
Number of buffalo owned in 2019 \\
Number of pigs owned in 2019 & 0.77 \\
Number of goats owned in 2019 & 0.54 \\
Area of grazing land in 2019 & 0.65 \\
Income from raising livestock in 2019 & 0.49 \\
Center of gravity & 0.72 \\
Hmong & -1.27 \\
Khmu & 0.83 \\
\end{tabular}

Table 5. Results of a canonical discriminant analysis (CDA) using the explanatory variables mentioned in Table 4 .

\begin{tabular}{ccccc}
\hline & & \multicolumn{3}{c}{ Predicted Ethnic Group } \\
\cline { 3 - 5 } & & Hmong & Khmu & Total \\
\hline \multirow{3}{*}{$\begin{array}{c}\text { Original ethnic } \\
\text { group }\end{array}$} & Hmong & 30 & 7 & 37 \\
& & $81.1 \%$ & $18.9 \%$ & $100 \%$ \\
& \multirow{2}{*}{ Khmu } & 4 & 19 & 23 \\
& & $17.4 \%$ & $82.6 \%$ & $100 \%$ \\
\hline
\end{tabular}




\subsection{Current Status of the Community}

To understand the current status of the community in terms of the distribution of owned land-use rights and livestock and of the importance (value) of cooperation within the community, a PCA with variables related to owned land-use rights, income generation and cooperation was applied to the sample households. The PCA extracted two principal components (PCs), which accounted for $68.9 \%$ of the total variance (Table 6). From the extracted PCs, PC1 explained $39.8 \%$ of the variance-this was interpreted as overall capital, because annual income showed the highest value; all the variables, moreover, had positive values. PC2, which explained $29.2 \%$ of the variance, identified the household characteristics associated with valuing cooperation within the community; variables representing cooperation had positive values while assets and income had negative values (Table 6).

Table 6. Factor loadings of principal components (PCs) 1 and 2 for households obtained from the principal component analysis (PCA).

\begin{tabular}{ccc}
\hline Explanatory Variables & \multicolumn{2}{c}{ Principal Component (PC) } \\
\cline { 2 - 3 } & $\mathbf{1}$ & $\mathbf{2}$ \\
\hline Total land area in 2013 & 0.46 & -0.30 \\
Total head of livestock in 2019 & 0.69 & -0.50 \\
Annual income in 2019 & 0.77 & -0.43 \\
Importance of knowledge sharing in 2019 & 0.61 & 0.67 \\
$\quad$ (5-point Likert scale) & & 0.70 \\
Importance of group activities in 2019 & 0.58 & 29.16 \\
(5-point Likert scale) & & 68.93 \\
$\quad$ \% variance & 39.77 & \\
Accumulated \% & &
\end{tabular}

A scatter plot was prepared (Figure 3) to visualize the distribution patterns of households according to support type along the two PCs. Each point in the diagram shows sample households and the different symbols represent different support types: type A, support in the first phase (from 2011 to 2014); type B, support in the second phase (from 2013 to 2018); type C, support in both phases and type D, no support. Type C showed notable characteristics; it was distributed mainly in Quadrant 4, which meant that type C households had relatively large capital and assigned less value to cooperation within the community. Importantly, those households' heads were mainly village authorities such as a village head and a member of the land and forest management committee. Many type A households were plotted in Quadrant 3, while type B households did not show particular characteristics. A number of type D households were plotted in Quadrant 2, which meant those households valued cooperation within the community but had relatively fewer land-use rights. The foregoing household characteristics, described as a function of support or lack thereof, showed that there were differences in levels of acceptance of new land-use activities (supports) and that associated transitions caused the income gap among households to increase (i.e., increase in the Gini coefficient as mentioned above) at the village level. 


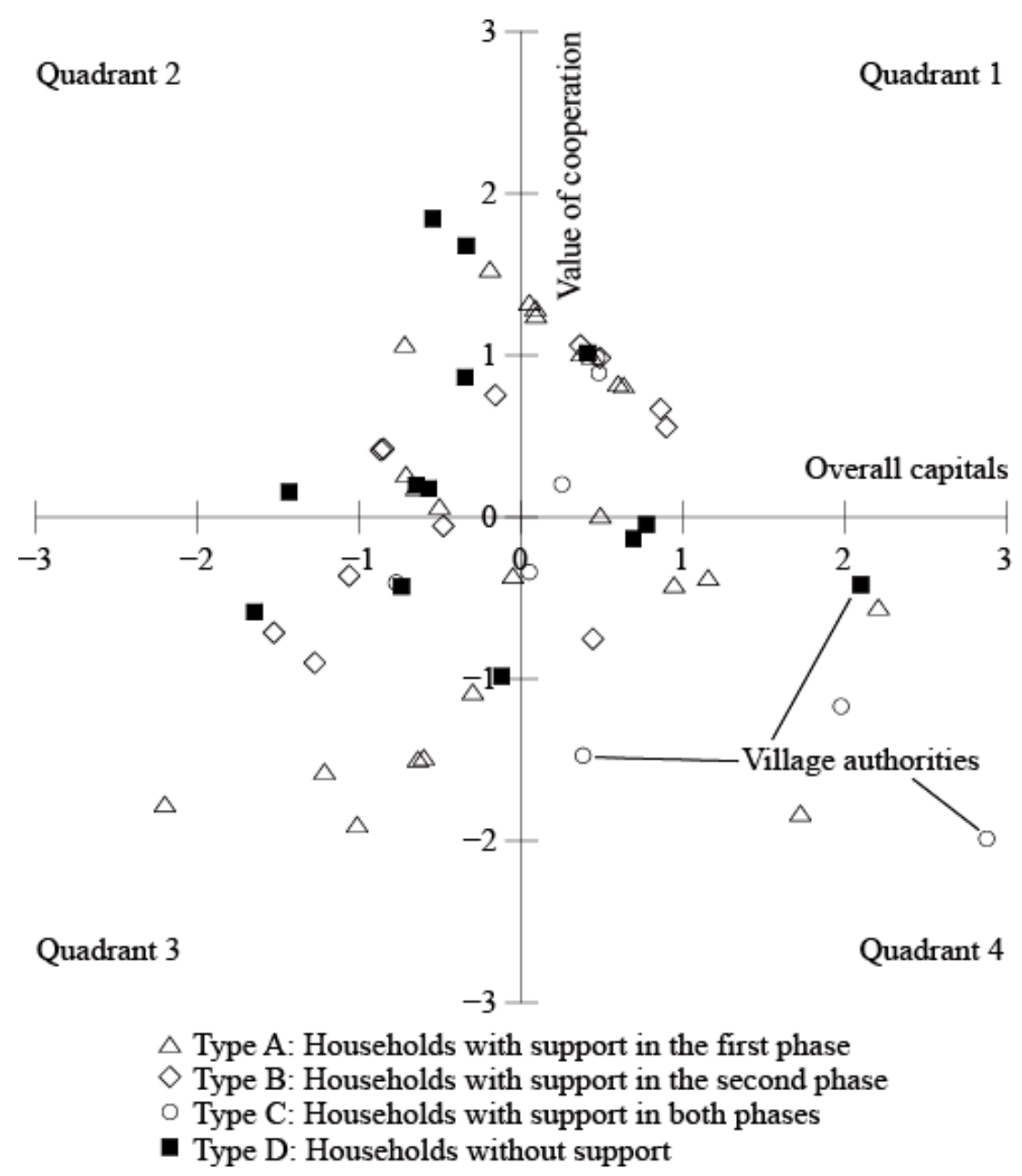

Figure 3. Distribution (factor scores) of surveyed households on two principal components (PCs) by support type. PC1 (asset) is used as the x-axis and PC2 (value of cooperation) is used as the y-axis. Note: three households plotted in Quadrant 4 were village authorities.

\section{Discussion}

The present research revealed that the Hmong ethnic group had more effectively incorporated the new land-use activities than the Khmu because they owned more grazing land and livestock throughout the study period. Hiratsuka et al. [23], who conducted a survey in the HKVC, reported that the Hmong owned more land than the Khmu. According to Phouyyavong et al. [32], the Hmong tended to have a larger land area because they had saved capital from cash crop cultivation to buy agricultural land. Their survey also indicated that, because of their greater land ownership, the Hmong could afford to convert fallow land to grazing land, whereas it was more difficult for the Khmu to raise large quantities of livestock because they did not have enough grazing land. Furthermore, it was suggested that the lifestyle of the Hmong was more reliant on economic activities (income-generation), while the Khmu relied more on natural resources, especially NTFPs and shifting cultivation. These two points can be considered as "financial capital", which reflects how each ethnic group makes their living and how they possess land and livestock assets on the basis of the Sustainable Livelihoods Approach [33]. Additionally, comments from focal group discussions with village authorities indicated that the Hmong were good at maintaining their livelihood by planning ahead. They also tended to have more family members than the Khmu, which provided a larger labor force [23,34]. Therefore, the Hmong can be viewed as well-positioned to benefit from new land-use activities. These characteristics can be considered as "human capital" for each ethnic group according to the Sustainable Livelihoods Approach [33]. 
Apart from differences in ethnicity, the results of the PCA indicated two additional points: (1) households that originally possessed relatively large assets and/or had higher social status tended to increase their capital easily and by greater amounts; (2) households that received direct financial support (type $\mathrm{A}$ and $\mathrm{C}$ ) tend to value community cooperation less and focus more on increasing their own assets. This can be explained by the characteristics of each phase of support: the first phase supported villagers financially in purchasing livestock, while the second phase focused on training and on knowledge and technology transfer. Chhatre et al. [35] noted that the village elite tended to make the most use of the support from REDD+, which lead to widening inequality. This means that support that relies on land resources that reflect a community's hierarchy may make disparities more apparent within the community, even though the type of support is decided on the basis of villagers' needs. Figure 3 indicated, moreover, that households that took financial support were likely to assign less value to cooperation in the community. Without considering the different characteristics of ethnicities and socioeconomic conditions, new land-use activities might contribute to widening the income gap between the two ethnic groups as well as to the decline in bonding social capital [36], which is viewed as an important factor for sustainable natural resource management [37]. The introduction of new land-use activities that are strongly related to livelihoods in rural areas should consider the context of social safeguards introduced by the UNFCCC [5]. In addition, to implement stable and sustainable land-use activities in rural areas, it is important to comprehensively consider land-use policies that maintain a balance between both the national level which mainly targets economic growth and GHG management and village or ground level activities that improve local livelihoods.

More broadly, when REDD+ and/or other land-use projects are implemented at the village level, socioeconomic factors, especially differences in the original possession of assets, must be considered [38,39]. It is vital to understand the characteristics and heterogeneity of local communities and to reflect them in ground level implementation to ensure distributional equity [40] even at the village level.

Author Contributions: Conceptualization, N.K.; methodology, N.K. and M.H.; investigation, N.K., C.B., P.S. and C.P.; writing-original draft preparation, N.K.; writing-review and editing, M.H. All authors have read and agreed to the published version of the manuscript.

Funding: This work was supported by The Ministry of the Environment, Japan.

Institutional Review Board Statement: Not applicable.

Informed Consent Statement: Not applicable.

Data Availability Statement: Not applicable.

Acknowledgments: We received valuable comments from Miki Toda and Hozumi Hashiguchi (Waseda University) and researchers at the National Agriculture and Forestry Research Institute, Lao PDR.

Conflicts of Interest: The authors declare no conflict of interest.

\section{References}

1. Intergovernmental Panel on Climate Change, Climate Change and Land: An IPCC Special Report on Climate Change, Desertification, Land Degradation, Sustainable Land Management, Food Security, and Greenhouse Gas Fluxes in Terrestrial Ecosystems; Intergovernmental panel on Climate Change: Geneva, Switzerland, 2019.

2. Seymour, F.; Harris, N.L. Reducing tropical deforestation. Science 2019, 365, 756-757. [CrossRef]

3. Curtis, P.G.; Slay, C.M.; Harris, N.L.; Tyukavina, A.; Hansen, M.C. Classifying drivers of global forest loss. Science 2018, 361, 1108-1111. [CrossRef] [PubMed]

4. McDermott, C.L.; Coad, L.; Helfgott, A.; Schroeder, H. Operationalizing social safeguards in REDD+: Actors, interests and ideas. Environ. Sci. Policy 2012, 21, 63-72. [CrossRef]

5. United Nations Framework Convention on Climate Change, The Cancun Agreements: Outcome of the Work of the Ad Hoc Working Group on Long-Term Cooperative Action under the Convention (Decision 1/CP.16). Available online: https://unfccc. int/resource/docs/2010/cop16/eng/07a01.pdf (accessed on 10 March 2021). 
6. Ehara, M.; Hyakumura, K.; Yokota, Y. REDD+ initiatives for safeguarding biodiversity and ecosystem services: Harmonizing sets of standards for national application. J. For. Res. 2014, 19, 427-436. [CrossRef]

7. Visseren-Hamakers, I.J.; McDermott, C.; Vijge, M.J.; Cashore, B. Trade-offs, co-benefits and safeguards: Current debates on the breadth of REDD+. Curr. Opin. Environ. Sustain. 2012, 4, 646-653. [CrossRef]

8. Angelsen, A.; Jagger, P.; Babigumira, R.; Belcher, B.; Hogarth, N.J.; Bauch, S.; Börner, J.; Smith-Hall, C.; Wunder, S. Environmental income and rural livelihoods: A global-comparative analysis. World Dev. 2014, 64, S12-S28. [CrossRef]

9. Ehara, M.; Hyakumura, K.; Nomura, H.; Matsuura, T.; Sokh, H.; Leng, C. Identifying characteristics of households affected by deforestation in their fuelwood and non-timber forest product collections: Case study in Kampong Thom Province, Cambodia. Land Use Policy 2016, 52, 92-102. [CrossRef]

10. Kimura, K.; Kobayashi, S.; Yoneda, R. The economic evaluation on the nontimber forest products collected in the rural areas in central Laos-case study on N Village in Fuang District, Vientiane Prefecture. Env. Inf. Sci. 2014, 28, 55-58.

11. Sakai, S.; Choy, Y.K.; Kishimoto-Yamada, K.; Takano, K.T.; Ichikawa, M.; Samejima, H.; Kato, Y.; Soda, R.; Ushio, M.; Saizen, I. Social and ecological factors associated with the use of non-timber forest products by people in rural Borneo. Biol. Conserv. 2016, 204, 340-349. [CrossRef]

12. Duchelle, A.E.; Simonet, G.; Sunderlin, W.D.; Wunder, S. What is REDD+ achieving on the ground? Curr. Opin. Environ. Sustain. 2018, 32, 134-140. [CrossRef]

13. Atela, J.O.; Minang, P.A.; Quinn, C.H.; Duguma, L.A. Implementing REDD+ at the local level: Assessing the key enablers for credible mitigation and sustainable livelihood outcomes. J. Environ. Manag. 2015, 157, 238-249. [CrossRef] [PubMed]

14. Sharma, B.P.; Shyamsundar, P.; Nepal, M.; Pattanayak, S.K.; Karky, B.S. Costs, cobenefits, and community responses to REDD+ a case study from Nepal. Ecol. Soc. 2017, 22, 34. [CrossRef]

15. Bayrak, M.M.; Marafa, L.M. Ten years of REDD+: A critical review of the impact of REDD+ on forest-dependent communities. Sustainability 2016, 8, 620. [CrossRef]

16. Mutabazi, K.D.; George, C.; Dos Santos, A.; Felister, M. Livelihood implications of REDD+ and costs-benefits of agricultural intensification in REDD+ pilot area of Kilosa, Tanzania. J. Ecosyst. Ecography 2014, 4, 1000144. [CrossRef]

17. Maharani, C.D.; Moeliono, M.; Wong, G.Y.; Brockhaus, M.; Carmenta, R.; Kallio, M. Development and equity: A gendered inquiry in a swidden landscape. For. Policy Econ. 2019, 101, 120-128. [CrossRef]

18. Rakatama, A.; Pandit, R.; Ma, C.; Iftekhar, S. The costs and benefits of REDD+: A review of the literature. For. Policy Econ. 2017, 75, 103-111. [CrossRef]

19. Satyal, P.; Corbera, E.; Dawson, N.; Dhungana, H.; Maskey, G. Justice-related impacts and social differentiation dynamics in Nepal's REDD+ projects. For. Policy Econ. 2020, 117, 102203. [CrossRef]

20. Ministry of Agriculture Forestry of the Lao People's Democratic Republic. Lao Census of Agriculture 2010/11: Analysis of Selected Themes; Ministry of Agriculture and Forestry, Government of the Lao People's Democratic Republic: Vientiane, Laos, 2014.

21. Hiratsuka, M.; Tsuzuki, H.; Suzuki, K.; Nanaumi, T.; Furuta, T.; Niitsuma, K.; Phongoudome, C.; Amano, M. Living biomass of fallow areas under a REDD+ project in mountainous terrain of Northern Laos. J. For. Res. 2018, 23, 56-63. [CrossRef]

22. Kiyono, Y.; Ochiai, Y.; Chiba, Y.; Asai, H.; Saito, K.; Shiraiwa, T.; Horie, T.; Songnoukhai, V.; Navongxai, V.; Inoue, Y. Predicting chronosequential changes in carbon stocks of pachymorph bamboo communities in slash-and-burn agricultural fallow, northern Lao People's Democratic Republic. J. For. Res. 2007, 12, 371-383. [CrossRef]

23. Hiratsuka, M.; Bounithiphonh, C.; Sichanthongthip, P.; Furuta, T.; Suzuki, K.; Kobayashi, N.; Chikaraishi, H.; Phongoudome, C.; Amano, M. Variations in village-level performances related to reducing deforestation and forest degradation associated with a REDD+ project in northern Lao People's Democratic Republic. Environ. Dev. Sustain. 2021, 23, 2762-2784. [CrossRef]

24. Phouyyavong, K.; Tomita, S.; Yokoyama, S. Smallholder's labor allocation for livelihood diversification: A case study in an upland village in northern Laos. Tropics 2020, 29, 9-24. [CrossRef]

25. Japan International Cooperation Aency. Validation and Registration of the Project on REDD Plus through Participatory Land and Forest Management for Avoiding Deforestation in Lao PDR; Japan International Cooperation Aency: Tokyo, Japan, 2014.

26. Vongsiharath, V. Forest Cover and Land-Use Changes in Lao PDR: According to the National Forest Reconnaissance Survey; Department of Forestry: Vientiane, Laos, 2011; pp. 75-116.

27. Yokoyama, S. Forest, ethnicity and settlement in the mountainous area of northern Laos. Jpn. J. Southeast. Asian Stud. 2004, 42, 132-156.

28. Schlemmer, G. Community Livelihoods Analysis; IUCN/MAF: Vientiane, Laos, 2002.

29. Yoshikura, T.; Amano, M.; Chikaraishi, H.; Supriyanto, B.; Wardhana, D. Evaluation of appropriate identification of deforestation agents and drivers for designing REDD+ readiness activities through an examination of the area around Gunung Palung national park, Indonesia. Open J. For. 2016, 6, 106-122. [CrossRef]

30. Hiratsuka, M.; Nakama, E.; Satriadi, T.; Fauzi, H.; Aryadi, M.; Morikawa, Y. An approach to achieve sustainable development goals through participatory land and forest conservation: A case study in South Kalimantan Province, Indonesia. J. Sustain. For. 2019, 38, 558-571. [CrossRef]

31. Department for International Development of the United Kingdom. Sustainable Livelihoods Guidance Sheets; DFID: London, UK, 1999.

32. Phouyyavong, K.; Tomita, S.; Yokoyama, S. Impact of forage introduction on cattle grazing practices and crop-livestock systems: A case study in an upland village in northern Laos. Rangel. J. 2019, 41, 323-334. [CrossRef]

33. Scoones, I. Sustainable Rural Livelihoods: A Framework for Analysis; IDS: Brighton, UK, 1998. 
34. Iwadare, M.; Hiratsuka, M. Adapted REDD plus Based on Local People's Capabilities: A Case Study from Luang Prabang Province, Lao PDR. Open J. For. 2017, 7, 228. [CrossRef]

35. Chhatre, A.; Lakhanpal, S.; Larson, A.M.; Nelson, F.; Ojha, H.; Rao, J. Social safeguards and co-benefits in REDD+: A review of the adjacent possible. Curr. Opin. Environ. Sustain. 2012, 4, 654-660. [CrossRef]

36. Putnam, R.D. Democracies in Flux: The Evolution of Social Capital in Contemporary Society; Oxford University Press: Oxford, UK, 2004.

37. Nath, T.K.; Inoue, M.; Pretty, J. Formation and function of social capital for forest resource management and the improved livelihoods of indigenous people in Bangladesh. J. Rural Community Dev. 2010, 5, 104-122.

38. Nathan, I.; Pasgaard, M. Is REDD+ effective, efficient, and equitable? Learning from a REDD+ project in Northern Cambodia. Geoforum 2017, 83, 26-38.

39. West, T.A.; Grogan, K.A.; Swisher, M.E.; Caviglia-Harris, J.L.; Sills, E.O.; Roberts, D.A.; Harris, D.; Putz, F.E. Impacts of REDD+ payments on a coupled human-natural system in Amazonia. Ecosyst. Serv. 2018, 33, 68-76. [CrossRef]

40. McDermott, M.; Mahanty, S.; Schreckenberg, K. Examining equity: A multidimensional framework for assessing equity in payments for ecosystem services. Environ. Sci. Policy 2013, 33, 416-427. [CrossRef] 